\title{
$X V$. On certain changes of colour, induced by chemical and other agents, in the membrane lining the choroid coat of the eye; in reply to an editorial note in Lond. and Edin. Phil. Mag. and Journ., vol. i. p. 115
}

\section{G.H. Fielding Esq. M.R.C.S.}

To cite this article: G.H. Fielding Esq. M.R.C.S. (1833) XV. On certain changes of colour, induced by chemical and other agents, in the membrane lining the choroid coat of the eye; in reply to an editorial note in Lond. and Edin. Phil. Mag. and Journ., vol. i. p. 115, Philosophical Magazine Series 3, 3:14, 87-89, DOI: 10.1080/14786443308648129

To link to this article: http://dx.doi.org/10.1080/14786443308648129

册 Published online: 01 Jun 2009.

Submit your article to this journal

Џll Article views: 2

Q

View related articles $₫$ 
Strontianite.-The Arragonite of the Causeway contains a small portion of Strontian.

Alum.-Occurs efflorescent on the Slate Clay of the Lias formation at White Head near Carrickfergus; also at Coal Island, Derry: Giesecké.

Aluminite.-In Trap at Gerron Point and Portrush.

Copper Pyrites. - With Galena, Newtonards, Down.

Iron Pyrites.-A bounds in Trap and other rocks.

Magnetic Iron Ore.-Occurs in great abundance in Trap at Portmuck, Island Magee, where it was first found by my friend Mr. M'Adam; it is crystallized in octahedrons ; lustre splendent.

Specular Iron.-Not uncommon in our Trap Rocks, crystallized in rhomboids.

Micaceous Iron Ore-In several places in Mourne Mountains. Anhydrous Bisilicate and anhydrous Disilicate of Iron have been found in Mourne by Mr. P. Doran, and recognised by Dr. Thomson. Red Hamætite, Clay Iron Stone, and Bog Iron Ore are met with in several places.

Galena and Green Phosphate of Lead.- Occur in the Newtonards lead mines, Down.

Radiated Gray Antimony.-Said by Sir C. Giesecké to occur near Londonderry.

Rutile.-Occurs in Quartz in Mourne.

Coal.-Its different varieties are common.

Amber.-Said to occur in the Coal of Rathlin, in small bits.

Belfast Academy, Feb. 12, 1833.

XV. On certain Changes of Colour, induced by chemical and other Agents, in the Membrane lining the Choroid Coat of the Eye; in Reply to an Editorial Note in Lond. and Edin. Phil. Mag. and Journ., vol. i. p. 115. By G. H. FieLDING, Esq. M.R.C.S. Curator of Comparative Anatomy to the Hull Literary and Philosophical Society.

To the Editors of the Philosophical Magazine and Journal.

Gentlemen,

T BEG leave to send you the following reply to a note appended by you, to a communication of mine in vol. i. page 115. of your New Series. For that note I feel much obliged to you; inasmuch as it led to further investigation, and to another entirely novel, and I think decisive experiment on the point. I am, Gentlemen, Your obedient Servant,

Greo. H. Fielding.

The part of my communication to which your remarks apply is the following: "6thly. It is possible by chemical agents (which, according to Bichat, have not the slightest effect on the pigmentum of the eye) to destroy and restore these colours at pleasure. Take a section of a beast's eye in which the colours are vivid, and dip it into any dilute acid (nitric, muriatic or sulphuric), you will perceive the colours immediately begin 


\section{8}

Mr. G. H. Fielding on a nete Membrane of the Eye.

to fade; now dip the portion in cold water, and on taking it out you will find the colours have disappeared; dip it again into the acid, and the colours will reappear as if by the touch of a magic wand; immerse it again in the water, and they will dis. appear; and so on, as often as you please. The same effect is produced by a solution of ammonia. With a pigment this could not occur; and my impression is, that these beautiful colours depend upon the thickness and disposition of the thin laminæ, of which, by dissection, I can prove this membrane to be composed. 'The cause of the disappearance and reproduction of the colours by chemical agency, I conceive to be merely the effects of heat and cold upon these thin plates, causing alternate expansion and contraction." Your observation is as follows: "Are not these changes of colour more probably referrible to the alterations of texture necessarily induced upon so delicate an organized structure by the application of chemical agents?"

Now, Gentlemen, the main object of my argument is to prove that the part in question is membrane, and not pigment. With this I think you seem to agree, by your use of the words "organized structure;" but you feel disposed to think that the curious changes in appearance in the experiment above detailed, are owing to some actual change in texture produced by chemical means.

If, therefore, I can show that these changes may be exhibited without the intervention of chemical agency, it will suffice both to satisfy your objection, and to strengthen my own position.

In the first place, $I$ should argue that if by any of the means that I have named, we had actually altered the texture of an organized part, we could not have restored it to its primary state again at pleasure; and therefore, if the colour had once been discharged, because of this actual alteration effected chemically in the texture, it would have remained discharged. But to prove my opinion that the singular phænomena detailed in the experiment are the simple result of changes produced in the actual thickness of the membrane by alternate expansion and contraction from alternate heat and cold produced by the acid and the water, and not from any chemical effect on the texture of the membrane, I think the following experiment will be sufficient.

Carefully detach the choroid membrane of a beast's eye from the sclerotica, remove the humours and the retina, and wash off all the brown pigment with water and a camel's hair brush. Then suspend the choroides in a current of air to dry. Observe carefully the nature of the bright colours of the mem- 


\section{Mr. J. Davies on the Spontaneous Combustion of Charcoal. 89}

brana versicolor on the internal surface when wet. As soon as the whole is thoroughly dry, examine it again, and you will find that all the colours have vanished. Immerse the collapsed membrane in water (or for more expedition in tepid water), and as the parts are gradually expanded you will find that the colours will be restored as beautiful as ever. This you may repeat as often as you like, with the same result.

In the choroid of a sheep, which I had injected minutely with vermilion, the effect of this experiment was most beautiful. The original colour of the membrana versicolor was a rich blue, but when dry the red injection was alone visible. With a little management I contrived to get it under the field of my microscope so as to see the actual process of the change. The blue surface came stealing over the red injection like a cloud, and gradually increased in density till the injection was fairly obscured by it.

XVI. An Attempt to assign the Cause of the Spontaneous Combustion of Charcoal. By.Mr. JoHn Davies, Member of the Wernerian Society of Edinburgh, \&c. and Lecturer on Chemistry, \& c.*

I $\mathrm{N}$ the interesting paper which has just been readt, no attempt has been made by the author of it to furnish an explanation of the phænomenon which he has established and described: and as every inquiring mind will direct its attention to a rationale of the operation, I presume that some remarks which have occurred to me within the last few days, and which may at least supply some aid in the discussion, may be, without impropriety, appended to the paper. These remarks, though theoretical, are countenanced by experimental analogies, which, if they fail to establish the accuracy of the speculation, may at least excuse its introduction.

A statement of the mode in which the charcoal in question is made, will be necessary in the subsequent explanation. Small fragments of wood, generally stripped of their bark, are put into iron cylinders, and exposed to intense heat, in order to effect the distillation of the volatile constituents for the manufacture of iron liquor. Now Mr. Brunner resorted to a similar procedure in obtaining potassium from potash and charcoal; and, as we know that potash may be procured

* Read before the Literary and Philosophical Society of Manchester, November 4, 1831 ; and now communicated by the Author.

+ Mr. Davies here alludes to Mr. Hadfield's paper on the same subject, given in our last Number, p. 1.-Eviт.

Third Series. Vol. 3. No. 14. Aug. 1833. 